УДК 821'06.09

\author{
Смаровоз Ірина, \\ аспірантка кафедри української \\ та зарубіжної літератур \\ і порівняльного літературознавства \\ Бердянський державний \\ педагогічний університет
}

\title{
ПОВСЯКДЕННЯ У ЛІТЕРАТУРОЗНАВЧОМУ ДИСКУРСІ ОСТАННІХ ДЕСЯТИЛІТЬ
}

\begin{abstract}
У статті аналізуютъся праці літературознавців пов'язані із дослідженням феномену повсякденності, розглядаютъся підходи до визначення терміну «повсякдення», його структури та методологіі y літературознавчому дискурсі. На основі аналізу досліджень літературознавців зроблені висновки про те, щоскладність аналізу феномена повсякденності полягае у великій різноманітності $i$ неоднозначності його інтерпретацій.
\end{abstract}

Ключові слова: повсякдення, життевий світ, структура, побут, буття, динамічна система, історичністъ, методологія, літературознавство, дискурс.

Smarovoz I. Everday Life the Literary discourse of modern decades. The article analyzes literary critics works studying the phenomenon of everyday life, approaches of defining the term "everyday life", its structure and methodology in literary discourse. The term "everyday life", which was introduced by Sigmund Freud in 1901, did not immediately gain popularity in literary studies. It gradually became the subject of interest in the variety of sciences, such as: history, sociology, philosophy, cultural studies and eventually literary studies. Therefore, the problem of "everyday life" phenomenon needs the interdisciplinary approach of its investigation. Every field of science defines this term in its own way. It is quite difficult to develop a universal structure of everyday life that would fit into all historical periods, types of writings and writers' worldviews. Depending on changes in values, norms of people's lives and writers' worldviews, new elements may be added to the structure of everyday life. All the elements of human everyday life can be considered as integral elements of everyday life, hence we tend to believe that everyday life is a dynamic system, which is inherent in historicity. In addition, the concept of everyday life is characterized by temporal and spatial dimensions. The character reveals and fully shows his personality only in the private space. A versatile analysis of the character's everyday life allows the researcher to penetrate into his character traits and inner world more deeply, to explain his actions and their motives. After all, nothing can reflect the inner world of a person better than the objects by which he fills his living space.

Researchers point out that the analysis of everyday life in a literary text is often carried out on the principle of oppositional categories: daily routine being, weekdays - holidays, spirituality - despirituality. Depending on the 
semantics of the concept "everyday life", its synonyms can be the concepts of "daily routine" and "daily life". Literary researchers do not aim to characterize "everyday life" in theoretical way, but perceive it as a simple and understandable concept.

Based on the analysis of the literary critics studies, it is concluded that the complexity of this phenomenon analyzing lies in the great variety and ambiguity of its interpretations.

Key words: everyday life, lifeworld, structure, mode of life, existence, dynamic system, historicity, methodology, literary studies, discourse.

Постановка проблеми. Повсякдення персонажа відіграє велику роль у розкритті його характеру, тому аналіз повсякденного життя персонажа набуває великої популярності у літературознавстві. 3 одного боку, до повсякдення, через його рутинність, буденність, склалося негативне ставлення. А з іншого, не можна відкинути той факт, що повсякдення - це нескінченне джерело пізнання людини. Проте у вітчизняній науці досить мало досліджень, присвячених проблемі повсякдення як літературознавчій категорії. Переважно це праці, в яких досліджується творчість окремих письменників, а повсякдення розглядається в межах предмета дослідження. На це звернула увагу Н. Колощук, аналізуючи дослідження молодих науковців за останні роки: «у монографічних дослідженнях творчості того чи іншого майстра слова проблема повсякдення, у тому числі й через аналіз предметної образності, як правило, білъш чи менш докладно розглядається» [3, с.321]. Тобто дослідники не ставлять собі за мету теоретично охарактеризувати повсякдення, а сприймають його як просте і зрозуміле поняття. Саме тому в сучасному літературознавчому дискурсі не існуе ні чіткого, однозначного визначення поняття повсякдення, ні його загальновизнаної структури, ні єдиної концепції. Тому проблема повсякдення є актуальною для сучасного літературознавства.

Аналіз останніх досліджень і публікацій. Останнім часом значну увагу дослідники, 3 різних галузей науки (В.Лелеко, Н. Колощук, С. Махліної О.Харлан та інші), почали приділяти феномену повсякдення. Термін «повсякдення» (Alltäglichkeit) ввів до наукового обігу Зигмунд Фройд ще у 1901 році («Психологія повсякденного життя»). Майже відразу він з'явився у полі зору гуманітарних наук завдяки Едмунду Гусерлю. Він, як батько феноменології, присвячував свої праці аналізові «життєвого світу» людини, першим звернув увагу на філософське осмислення сфер людської буденності, а тому його праці вважають загальнотеоретичними джерелами вивчення феномену повсякдення. 
76 Літератури світу: поетика, ментальність і духовність. 2020. Вип. 14

У другій половині ХІХ століття історики (М. Костомаров, Е. Віоллеле-Дюк, Е. Фукс та інші) у своїх дослідженнях просто описували довкілля людини, її родину, відпочинок, обряди, тіло. Таке ставлення до повсякдення було викликано тим, що його сприймали як маловартісну сферу в житті людини, в якій не відбувається нічого важливого, надзвичайного.

Як бачимо, довгий час внутрішній зміст повсякденності не брався до уваги. У 50-ті роки ХХ століття представники французької історичної школи, що об'єдналися навколо журналу «Аннали» (Л. Февр, М. Блок, $\Phi$. Бродель, Ж. Дюбі, Ж. Ле Гофф та ін.), почали вивчати ментальні структури повсякдення, відтворюючи історичний процес на основі аналізу динаміки життя людей. Врешті, повсякдення стало предметом дослідження цілого комплексу наук, таких як філософія, історія, соціологія, культурологія, лінгвістика.

Як зазначає В. Д. Лелеко, в останні роки ХХ століття повсякдення набирає популярності: «Повсякденне життя починає претендувати на високу культурну значимість, виходить на авансцену суспільного життя, знаходиться в центрі суспільної уваги» [6, с.3]. Крім того, аналізуючи семантику повсякдення, науковець робить висновок, що поняття «побут», «повсякдення» та «повсякденне життя» вживаються як синоніми. Проте наголошує на тому, що кожна наука i кожен науковий напрям по-своєму дають визначення цьому термінові, а тому: «Зістове наповнення поняття «повсякдення» визначається усвідомлено чи інтуїтивно обраним ракурсом сприйняття реальності, e результатом обраної методології дослідження $i$ визначення його nредмету» $[5$, с. 82]. Такий підхід до розуміння феномену повсякдення пояснює наявність великої кількості не ворогуючих теорій і поглядів, а навпаки, таких, що доповнюють чи уточнюють одна одну.

Отже, метою статті є систематизація існуючих поглядів сучасних літературознавців, спроба дати визначення поняттю «повсякдення» та з'ясувати його структуру.

Виклад основного матеріалу. Як уже зазначалося, літературознавство ще не сформувало свого єдиного підходу до аналізу повсякденності, а тому його методологічною основою є праці філософів, соціологів, культурологів та істориків присвячені дослідженню повсякдення. Проаналізувавши ці праці, О. Харлан робить висновок, що у світовій науці існують два розуміння історії повсякденності: «як реконструююча ментальний макроконтекст подієвої історій $i$ як реалізачія прийомів мікроісторичного аналізу» [11, с.50]. 
Літературознавець наголошуе на тому, що ці моделі існують не паралельно, а доповнюють одна одну в описі та аналізі повсякдення.

Спираючись на загальнотеоретичні дослідження повсякдення в галузі філософії, історії, психології, культурологї та аналізуючи образ повсякдення в творчості письменників, літературознавці створюють свою концепцію повсякдення. Наприклад, за словами Н. Колошук: «феноменологічний підхід у літературознавстві ототожнюе концепт повсякдення з поняттям «життевого світу», що постає як иілісний образ реальності» [2, с.321]. Але, на думку дослідниці повсякдення є ширшим поняттям ніж «життєвий світ». Важливо відзначити, що феноменологічний підхід не набув широкого розповсюдження в українському літературознавстві, а його принципи застосовуються лише як окремі елементи у літературознавчих дослідженнях.

На глибину поняття повсякдення звертає увагу i польська дослідниця Г.Борковська: «Писати про повсякденне життя це писати про щось інше ніж сам звичай, матеріальна сфера, ментальність, поведінка. Повсякдення виражає сутність суспільного відношення суб'єкта, його спосіб існування в світі» ${ }^{1}$ [13, с.38] (переклад з польської тут і далі наш - I. С.). Як бачимо, науковці наголошують на тому, що неможливо просто описувати повсякденне життя героя, не звертаючи уваги на його внутрішній зміст.

Подібний погляд на повсякдення, знаходимо у дослідженні С.Т. Махліної, яка вважає, що повсякденне життя людини, як в дзеркалі, відображається в інтер'єрі ㄲï помешкання:«Зазирнути в інтер'ер - майже те саме, що зазирнути в душу, побачити зафіксовані в речах смаки і звички людини» [7, с. 18]. Тому вважає інтер'єр одним із засобів творення образу персонажа: «Щоб розкрити характер того чи іншого героя, писъменник часто описував його iнmер'єp» [7, с. 18]. Не можемо не погодитися з цією думкою, адже ніщо не може відобразити внутрішній світ людини краще, ніж предмети, якими вона сама заповнює свій простір. Ніби уточнює цю думку Л. Тарнашинська, стверджуючи, що «у межах приватного простору через топоси повсякдення реалізуетъся незаперечна автентичність людини, ї справжсність, розкриваєтъся сутність особистості «без маски» [9, с. 31]. Як бачимо, приватний простір дозволяє людині розкритися, бути самою собою, що набагато складніше зробити в соціальному світі, де особистості доводиться грати ту чи іншу роль.

\footnotetext{
1"Pisać o życiu codziennymto pisać o czymś innym niż sam obyczaj, sfera materialna, mentalność, zachowania. Codzienność wyraża istotę społecznego nastawienia podmiotu, jego sposobistnienia w świecie".
} 
78 Літератури світу: поетика, ментальність і духовність. 2020. Bип. 14

К. Воротинцева виділяє дві моделі повсякдення, в рамках яких можуть виникати проміжні типи. Вона спирається на думку, що повсякденність у художньому творі може реалізуватися в його ціннісно-смисловій структурі: «Як відомо, внутрішній світ твору складається із подій, що складають фабульну дію і на рівні сюжету наділяються сенсом, тип иих подій, на нашу думку, ї можливість $i$ неможливість, визначається характером текстуально обормленой повсякденності» [2, с.44]. Виходячи із твердження, що важливим структурним елементом твору є подія, одним із можливих шляхів для аналізу структур повсякдення дослідниця вважає співвіднесення цих структур із подією. Але наголошує на тому, що не до всіх типів текстів можна застосувати цей метод, адже не всі тексти є подієвими. Тому дослідниця пропонує ще одну модель повсякденності: «Другий тип повсякденності - точніше, та межа, до якої може прагнути репрезентація повсякденності в літературному тексті, - являе собою структуру світу твору, в рамках якої можслива реалізація подій в значенні відхилення чи порушення норми» [2, с. 45]. Мова йдеться про тексти, в яких не існує протиставлення події і повсякденності, наприклад міфи і твори, написані на міфологічній основі, адже в цих текстах повсякденність є сакральною, а тому щось незрозуміле, магічне, нереальне включається в картину світу. «Для «сакралізованої» повсякденності втіленої у відповідній структурі світу твору, характерні иілісність, повнота, $i$ неможливість здійснювати подї̈ в сучасному розумінні: повсякденністю не передбачений акт, який розривав би ї̈ адже він зарані включений в структуру cвimy...» [1, c. 291].

Б. Попчик-Щенсна, погоджуючись із думкою Б. Вальденфельса, виділяє три складові в моделі повсякдення: «У своїx роздумах про повсякденність у драматичних творах опираюся на розрізненні трьох аспектів повсякденності: а) звичність, загальний порядок структура досвіду, б) сфера того, що конкретно очевидне і досяюне рівень досвіду, в) те, що замкнуте в собі $і$ скуте - простір досвідy» ${ }^{2}[14$, c. 16$]$. Свою модель дослідниця базує на досвіді особистості.

Т. Струкова, аналізуючи феномен повсякденності у літературознавстві, вихідною точкою до його розуміння вважає місце людини у

\footnotetext{
${ }^{2} \mathrm{~W}$ moich rozważanniach o codzienności w dramacie opieram się na rozróżnieniu trzech aspektów codzienności: a) złykłość, utarty porządek - strukturadoświadczeń, b) sfera tego, co konkretnie naoczne i uchwytne - poziom doświadczeń, c) to, co zamknięte w sobie i skrępowane - przestrzeń doświadczeń.
} 
літературному творі: «У центрі літературної рефлексї̈ знаходитъся людина, а тому сфера повсякдення в художнвому творі охоплюе різноманітні аспекти життя» [8, с. 78]. До цих аспектів дослідниця відносить: «по-перше, епізоди публічного життя людини, способи $i$ варіанти ї̈ пристосування до зовнішнього світу; по-друге, домашне, приватне життя персонажа, в яке включені побут $i$ буття в усіх їx проявах; по-трете, різноманіття емочійних проявів, спровокованих буденними обставинами» [8, с. 78-79]. Посилаючись на висновки Т.Струкової, можемо стверджувати, що категорії повсякдення притаманний просторовий вимір. Крім цього, дослідниця наголошує на тому, що повсякденню притаманна історичність, адже повсякдення однієї епохи відрізняється від повсякдення іншої епохи. Проаналізувавши, як реалізується природа повсякдення у різних історичних епохах та творчості окремих письменників, дослідниця робить висновок, що «феномен повсякдення по-своєму реалізуеться в різних культурно-історичних епохах, в межах естетичних напрямів та у різних писъменників» [8, с. 81]. Така точка зору дає можливість нам стверджувати, що досить важко виробити універсальну структуру повсякдення, яка б підходила до всіх історичних періодів, типів творів та світоглядів письменників. Це наштовхує нас на думку, що структура повсякдення повинна бути динамічною.

Про динамічність феномену повсякдення говорить М. Барановська. Вона звертає увагу на те, що залежно від зміни цінностей, норм життя людей і світогляду письменників до структури повсякдення можуть додаватися нові елементи. Доводить це дослідниця, порівнюючи творчість А. Свірщинської та В. Шимборської: «Проблема в тому, що з певної точки зору його можна розуміти як иілісність світу, в якій съогодні знаходять місче сфери, що колись вважслися чужими для повсякдення (наприклад, містика)» ${ }^{3}[12$, с. 256$]$.

О. Кучеренко, аналізуючи проблему повсякдення в одному з творів Томаса Гарді, наголошує на тому, що не можна розглядати повсякдення лише в побутовому аспекті, адже побутова й буттєва сфери в житті людини пов'язані настільки сильно, що розірвати їх неможливо. Саме тому обидві ці сфери повинні входити до структури повсякдення: «Художсній образ повсякденності складається тут із побутової $i$ буттевої складових» [4, с. 175].

\footnotetext{
${ }^{3} \mathrm{~W}$ tym problem, że z pewnego punktuwidzenia można ją rozumieć jako całość świata, w kturej znajdują dziśmiejsce sfery kiedyś uważane za całkowicie codzienności obce (naprzykład mistyka)
} 
80 Літератури світу: поетика, ментальність $і$ духовність. 2020. Bип. 14

Л. Тарнашинська зауважила, що в українській літературі активно використовували поетику повсякдення шістдесятники: «Саме $\ddot{\imath}_{\mathcal{M}}$ належить зреалізоване зусилля охудожнення повсякдення, вдала спроба надання йому сенсовості, значимості, певною мірою навіть сакральності, що вумовах тоталітарного суспільства сприймалося як виклик поетииі монументалізму, пафосного героїзму, колективного знеособлення» [9, с. 158]. На думку дослідниці, поняття повсякдення у шістдесятників будується на системі опозицій: «духовність бездуховність», «будень - свято». Така структура повсякдення у творчості шістдесятників пояснювалася викликами часу та усвідомленням митцями своєї місї і завдань літератури.

Підсумовуючи аналіз літературознавчих досліджень феномену повсякдення, Н. Колощук зазначає: «Осмислення відображсеного в літературному тексті повсякдення, як правило, здійснюеться за принципом опозищійності категорій побут - буття, що може набувати тричастинної структури: побут - буття - небуття. Чимало дослідників класичної літератури відзначають, з одного боку, предметність іреальність, а з другого - фантасмагоричність представленого нею світу повсякдення» [3, с.321]. Як бачимо, повсякдення піддається різнобічному аналізові, в залежності від обраних методів.

Висновки та перспективи подальших досліджень. Першими до аналізу повсякденного життя людини звернулися історики та філософи. Згодом «повсякдення» стало предметом дослідження цілого комплексу наук: філософії, історії, соціології, лінгвістики, а в останнє десятиліття воно набуває широкої популярності в сучасній гуманітарній науці, що є доказом того, що буденне життя людини стає предметом зацікавлення письменників та літературознавців. Літературознавці використовують праці філософів, соціологів та культурологів як теоретичну базу для своїх досліджень. Отже, дослідження повсякдення в літературознавстві має міждисциплінарний характер. Складність аналізу феномена повсякдення полягає у різноманітності і неоднозначності його інтерпретацій та відсутності теоретичних праць у літературознавстві, присвячених його дослідженню. Літературознавці не ставлять собі за мету вивчення «повсякдення» як літературознавчої категорї, а тому кожен розуміє його залежно від мети і завдань свого дослідження. Ми схильні до думки, що повсякдення - це динамічна система, якій притаманна історичність. Проаналізувавши праці українських та зарубіжних літературознавців (О. Харлан, Н. Колошук, Г. Борковської, С. Махліної, Л. Тарнашинської та інших), 
ми відмітили, що до структури повсякдення можна віднести все, 3 чого складається людське життя. Структура повсякдення залежатиме від жанру твору, ціннісної системи автора та мети дослідження. Однозначно можна ствердити, що різнобічний аналіз повсякденного життя героя дозволить дослідникові глибше розкрити його характер, внутрішній світ, пояснити вчинки та їх мотиви.

Перспективою подальшого дослідження, на нашу думку, буде вивчення досвіду ширшого кола літературознавців - представників різних національних наукових шкіл.

\section{Література}

1. Воротинцева К.А. Поэтика повседневности в аспекте действительности героя. Критика и семиотика. Вып. 14. Москва. 2010. C. 276-292.

2. Воротинцева К.А. Поэтика повседневности в литературном повествовании: теоретические аспекты. Чтение: рецепция и интерпретация : сб. науч. ст. : в 2 ч. Ч. 1 / редкол : Т. А. Автухович (отв. ред.) [и др.]. Гродно : ГрГУ, 2011. С. 42-48.

3. Колошук Н.Г. Повсякдення у дзеркалі мемуарної радянської літератури (В. Сосюра та інші). Актуальні проблеми слов'янської філології. Серія «Лінгвістика і літературознавство» : міжвуз. зб. наук. ст. Вип. XXVI. - Ч. II / гол. ред. В. А. Зарва. Бердянськ : БДПУ, 2012. С. 320-335.

4. Кучеренко О.В. Проблема повседневности в рассказе Томаса Гарди «Проповедник в затруднении». Социально-экономические явления и процессы. № 8. Тамбов : Изд-во Тамбовского гос. ун-та им. Г. Р. Державина, 2013. С. 173-180.

5. Лелеко В. Д. Пространство повседневности в европейской культуре. Санкт-Петербург : Санкт-Петербургский гос. ун-т культуры и искусств, 2002. С. 320.

6. Лелеко В.Д. Пространство повседневности как предмет культурологического анализа : автореф. дис. ... доктор культурологии: 24.00.01. Санкт-Петербург, 2002. 35 с.

7. Махлина С. Т. Повседневность в зеркале жилого интерьера. СанктПетербург : Алетейя, 2012. 256 с.

8. Струкова Т.Г. Проблема обыденности в дискурсе о литературе. Вестник Воронежского государственного университета. Серия: Философия. № 1 (23). 2017. С. 72-83. 
82 Літератури світу: поетика, ментальність і духовність. 2020. Bип.14

9. Тарнашинська Л. Б. Антропологічні практики повсякдення: людина як психологічна цілісність. До 80-річчя Євгена Гуцала. Слово і час. № 1. 2017. C. 18-36.

10. Тарнашинська Л.Б. Феномен повсякдення в структурі буденної свідомості героїв Валерія Шевчука. Філософськолітературознавчий аспект. Волинь - Житомирщина. Історикофілологічний збірник з регіональних проблем. Ч. 20. Збірник на честь 70-річчя почесного професора Житомирського державного університету імені Івана Франка, письменника Валерія Шевчука. Житомир : Вид-во ЖДУ ім. І. Франка. 2010. С. 158-175.

11. Харлан О. Д. Поетика повсякденності в «Щоденнику» Михайла Драй-Хмари. Дивослово, 2010. С. 50-54.

12. Baranowska M. Szymborska i Świrszczyńska: dwa bieguny codzienności. Teksty Drugie: teoria literatury, krytyka, interpretacja.1995. Nr 3/4 (33/34). S. 256-263.

13. Borkowska G. Życie codzienne jako kategoria literacka i badawcza (rekonesans). Codzienność w literaturze XIX (i XX) wieku. Od Adalberta Stifiera dowspółczesności / red. Grażyny Borkowskiej i Anety Mazur. Opole : Wydawnictwo Uniwersytetu Opolskiego, 2007. 509 s.

14. Popczyk-Szczęsna B. Doświadczenie codzienności w dramacie polskim po 1989 roku. Postscriptum Polonistyczne. 2011. Nr 2. S. 15-26. 